\title{
DO AVAL DADO POR MULHER CASADA SEM O CONSENTIMENTO DO MARIDO
}

\author{
Betina Treiger Grupenmacher* \\ Joaquim Miró Neto**
}

\begin{abstract}
*Pós-Graduanda do Curso de Mestrado da PUC-SP. **Prof. Adjunto do Depto de Direito Privado do Setor de Ciências Jurídicas da UFPR.
\end{abstract}

É questão doutrinária e jurisprudencialmente controvertida. a que versa sobre a nulidade ou não do aval dado pela mulher sem o consentimento do marido.

A controvérsia surgiu concretamente após o advento do Estatuto da Mulher Casada (Lei 4.121 de 24-08-62) que, em seu art. 30, contém disposição aparentemente conflitante com o preceituado pelo art. 242, inciso IV do Código Civil.

Dispõe 0 art. 3 ? da Lei 4.121 de 27-08-62: "Pelos títulos de dívida de qualquer natureza, firmados por um só dos cônjuges, ainda que casados pelo regime de comunhão universal, somente responderão os bens particulares do signatário e os comuns até o limite de sua meação".

Já 0 art. 242, inciso IV do Código Civil, veda à mulher, sem o consentimento do marido, "contrair obrigações que possam importar em alheação de bens do casal".

Consoante se pode notar há entre as regras aludidas uma aparência de conflito no objeto por elas disposto, ou seja, de uma interpretação superficial das mesmas pode-se concluir pela existência de uma eventual antinomia.

Na lição de Tércio Sampaio Ferraz Jr., encontramos o exato conceito do que vem a ser antinomia. A antinomia jurídica, é "a oposição que ocorre entre duas normas contraditórias (total ou parcialmente), emanadas de autoridades competentes num mesmo âmbito normativo que colocam o sujeito numa posição insustentável pela ausência ou inconsistência de critérios aptos a permitir-lhes uma saída nos quadros de um ordenamento dado": (Tércio Sampaio Ferraz Jr. - Antinomia, in Enciclopédia Saraiva 
de Direito, p. 14, citado por Maria Helena Diniz - Conflito de Normas, p. 23 - 1987 - Saraiva).

Assim, ter-se-á antinomia, todas as vezes que se esteja diante de duas normas conflitantes entre si, sem que se saiba qual deverá ser aplicada em dado caso específico.

Quanto ao critério de solução classificam-se as antinomias em real e aparente. São aparentes aqueläs pásívíièis de solução, pela existência de critérios consubstanciados em normas pertencentes ao ordenamento jurídico vigente. Por outro lado são antinomias reais aqueias que mantém o destinatário da norma em uma posição insustentável ante a inexistência de critérios normativos para a solução da mesma.

Tércio Sampaio Ferraz Jr. e Alf Ross, substituem tal distinção por outra, afirmando que antinomia real vem a ser aquela em que a posição do sujeito é insustentável porque há: "a) lacuna de regras de solução, ou seja, ausência de critérios para solucioná-la, ou b) antinomia de segundo grau, ou melhor, conflito entre os critérios existentes, e antinomia aparente, o caso contrário". (Maria Helena Diniz - in Compêndio de Introdução à Ciência do Direito - p. 429, 1988 - Ed. Saraiva).

No caso de antinomia aparente se nos apresentam os seguintes critérios de solução: a) O hierárquico (lex superior derogat legi inferiori), b) o cronológico (lex posterior derogat legi priori) e o da especialidade (lex especiallis derogat legi generali).

Caso seja viável a aplicação de ditos critérios para a solução do conflito normativo o sujeito não se encontraria em uma posição insustentável, tem-se aqui uma antinomia aparente. Em não sendo, por outro lado, possível a remoção do conflito normativo, ante a impossibilidade de se verificar qual é a norma mais forte, surgirá a antinomia real ou lacuna de colisão, que será solucionada por meio dos princípios gerais do preenchimento de lacunas.

" $\mathrm{E}$ preciso não olvidar que havendo antinomia, ou mesmo lacuna de conflito, em casos excepcionais o valor "justum" deverá lograr entre duas normas incompatíveis, devendo-se seguir a mais justa ou a mais favorável, procurando salvaguardar a ordem pública ou social" (Bobbio, des critéres, in les Antinomies en droit, p. 237 e 245, Perelman, De la Justice, Bruxelles, Émile Bruâlant, 1945, p. 72, citado por Maria Helena Diniz, in Compêndio de Introdução à Ciência do Direito, p. 432).

Assim, ante os elementos acima apresentados, não há que se aventar a hipótese da existência de antinomia sequer aparente entre as regras preceituadas pelos arts. 3 o da Lei $4.121 / 62$ e o 242 , inciso IV do Código Civil, eis que os referidos mandamentos nor- 
mativos não se contradizem, ou seja, não se vislumbra qualquer contradição total ou parcial entre estes.

A antinomia, como se pode ver, só existe entre normas conflitantes, conflito este que se puder ser solucionado pelo critério hierárquico, cronológico ou da especialidade, configurará antinomia aparente, caso contrário, consubstanciar-se-á em antinomia real.

Com efeito, a redação do art. 242 , inciso IV do C.C. foi mantida mesmo após as modificaçṍes introduzidas pelo Estatuto da Mulher Casada, vez que, a Lei no 4.121 de 27-08-62, não foi instituida para emancipar a mulher casada. Tem sim, o precípuo objetivo de conferir maior proteção à sua meação contra atos decorrentes da má administração dos bens do casal, realizada pelo marido, que em muitos casos, antes do advento da Lei 4.121, importavam em total alheação dos bens do casal.

Nesse sentido temos a lição de Silvio Rodrigues que ensina: "O art. 3 o da Lei no 4.121/62 vai amparar, nesse passo, a mulher. Por aquelas dívidas só respondem os bens particulares do marido e os comuns até o montante de sua meação. De modo que, não havendo a esposa firmado os títulos de dívida, ao proceder-se à penhora dos bens comuns, poderá ela defender-se, pleiteando que se exclua da penhora, a metade dos bens comuns, objeto daquela penhora". (Silvio Rodrigues, Direito Civil, vol. 6 - Direito de Família, p. 165 - 1982 - Ed. Saraiva).

A proibição contida no inciso IV do art. 242 do C.C., em sua nova redação (que é o inciso VIII da redação originária desse mesmo dispositivo legal) permaneceu, como aliás era de se esperar, pois caso contrário, a mulher passaria a ter efetiva ingerência sobre a administração da metađe dos bens pertencentes ao casal, sendo-lhe permitido, sem a outorga uxória do marido, administrador dos bens comuns, contrair obrigações que poderiam importar em alheação de bens do casal.

Esclareça-se, por outro lado, que a proibição contida no Códido Civil, art. 242, inciso IV, já possuía ressalvas anteriormente à Lei 4.121, nas hipóteses do art. 251, quando a mulher assumisse a administração dos bens do casal, ou ainda quando fosse a mulher comerciante (nesse sentido as lições de Paulo Lacerda (A Cambial no Direito Bras., 4. a ed., p. 165, notas 211-2), Whitaker (Letra de Câmbio, p. 109, Ed. Rev. dos Trib., Magarino Torres (Nota Promissória, vol. I, 1.118, ed. Forense), Pontes de Miranda (Tratado de D. Privado, voil. XXXV/262, 3.954, no 1, ed. Barsol), Waldemar Ferreira (Trat. de D. Comercial, vol. 81.190, ed. Saraiva), exercesse qualquer outra profissão ou finalmente se se encai-

\begin{tabular}{lllll}
\hline R. Fac. Direito Curitiba & a. 25 & n. 25 & p. 183-188, 1989 & 185
\end{tabular} 
xasse na situação descrita nos incisos I e II do art. 247 do Código Civil.

É iniludível que o art. 3 o da Lei 4.121, veio salvaguardar 03 interesses da mulher casada, a qual não tem todavia a administração, ainda que parcial e esporádica, dos bens do casal, ou os do marido, o que a compatibiliza com a proibição do inciso IV do art. 242, nos casos em que a lei (art. 251 do C.C.) autorize o exercício da administração dos bens do casal pela mulher, hipótese em que, às obrigações por ela contraídas, sem que o marido as firme, não responderão os bens comuns senão até o limite de sua meação.

Wilson Bussada selecionou os seguintes aspectos relevantes da nulidade da emissão cambial por mulher casada, por falta de autorização marital: "1050 - ... Acontece mais. A obrigação cambiária em execução foi assumida por mulher casada sem autorização marital, o que a torna nula de pleno direito. "Não pode a mulher casada obrigar-se cambiariamente sem autorização do marido", decidiu o 10 Trib. de Alçada Cível do Est. de S.P. (RT 467/123). Vale a pena transcrever alguns fundamentos da decisão supra: “. . dispunha o Código Civil, no seu art. 224, no VIII, que a mulher casada, não podia, sem aut. do marido, contrair obrigações que possam importar em allheação de bens do casal. Daí a razão por que a doutrina era no sentido de que somente a mulher casada comerciante poderia se obrigar cambiariamente...". A própria lei no 4.121 de 27-08-1962, que regula a situação jurídica da mulher casada não alterou a proibição...", no art. 10 mantém a norma proibitiva. "A mulher casada continua dependendo da prévia autorização marital, para assumir cambiariamente, desde que não seja comerciante". (Código Civil Brasileiro - interpretado pelos Tribunais, vol. 2, Tomo III, 1981, p. 132 e segs.).

São diversas as situações em que o marido dá o aval sem o consentimento da mulher e que a mulher dá o aval sem o consentimento do marido.

Na primeira hipótese o aval é válido pois, o marido, não necessita como já exposto anteriormente, da outorga uxória para dá-lo. A mulher, por seu turno, desde que não abrangida nas exceções antes referidas, sempre necessita, antes e após o advento do estatuto da mulher casada, da aquiescência märital para obrigarse cambiariamente, seja emitindo, seja avalisando títulos de crédito.

Assim sendo, como já ficou patente, o preceito do art. $3^{0}$ da Lei 4.121 de 1962 regulou, na verdade, situações que vinham sendo reconhecidas anteriormente pela doutrina (PONTES DE MIRANDA), para os casos de aval prestado por homem casado, conforme

Curitiba

a. 25

n. 25

p. 183-188, 1989 
voto do Min. Barros Monteiro no julgamento do RE $66.703 \mathrm{de} \mathrm{Mi}$ nas Gerais - RTJ 51-139: "Aliás, invocam, ainda, as contra-razões, excelente julgado do Supremo Tribunal Federal, de que foi relator o Min. Prado Kelly e em que este com apoio na lição de Pontes de Miranda, mostra que mesmo antes da Lei 4.121, já em jurisprudência e em doutrina sustentavam que o aval prestado por homem casado, sem o consentimento da mulher, só obrigava á meação do marido ( $R E$ 60.453 julgado a 29-09-67).

Não se pode, pois, perder de vista o preceito geral do Código Civil, que veda à mulher assumir obrigações que importem em alheação de bens do casal, sem o consentimento do marido, no exame da aparente contrađição do preceito do art. 30 do Est. da Mulher Casada.

Infere-se pois, que o que há entre as regras do art. 3 ? da Lei 4.121 e o art. 242, inciso IV do Código Civil, é um aparente confli to. Isto posto não guardam os mencionados dispositivos qualquer contradição entre si. O que há é a mera aparência de um conflitó, que consoante se demonstrou nas considerações anteriores, não existe concretamente.

A aplicação da proibição contida no art. 242, inciso IV do C.C. pode, perfeitamente, ser realizada de forma conjunta e harmônica com a disposição do art. $3^{0}$ da Lei 4.121 , lançando-se mão da interpretação restritiva.

Muitas vezes o intêrprete e o aplicador da norma utilizam-sé da interpretação restritiva, restringindo a incidência do comando normativo, impedindo que produza efeitos injustos ou danosos, pois que suas palavras englobam hipótese que nelas, na realidade, não estão incluídas.

Acerca de tal ato interpretativo, convém esclarecer que não visa este, a restringir ou a reduzir a abrangência da norma. Oojetiva, tal espécie de interpretação, delimitar os limites ou fronteiras exatas, com o auxílio de elementos lógicos e de fatores jurídicosociais, viabilizando a aplicação justa da norma de modo que corresponda à sua conexão de sentido. (Maria Helena Diniz, in Compêndio de Introdução à Ciência do Direito, p. 393).

$\mathrm{Na}$ verdade, a interpretação restritiva não é uma técnica interpretativa, é sim um efeito do ato interpretativo.

O que se deve ter em consideração é o fim colimado pela norma e os valores jurídico-sociais que influiram no nascimento desta.

O hermeneuta, deve restringir-se: 1) ao espírito do texto normativo; 2) à eqüidade; 3) ao interesse geral; 4) ao paralelo entre a norma interpretada e outras, sobre idêntico objeto, contidos no mesmo diploma legal ou em outro. (Gezá Kiss, Gesetzesauslegung 
und ungeschriebens Recht, 1911, p. 25 e 26, citado por Carlos Maximiliano, Hermenêutica, p. 215, Limongi França, Formas e Aplicação, p. 49) citados por Maria Helena Diniz, in Compêndio de Introdução à Ciência do Direito, p. 393).

Tem-se, assim, a interpretação restritiva de um dos preceitos, para conciliar-se com o outro. Nesse caso, atribui-se a regra interpretada, dentro dos inúmeros sentidos que ela admite, o que a integra de forma harmônica, ao sistema jurídico vigente.

Portanto, é clara a inexistência de antinomia entre os arts 242, inciso IV do Código Civil e 3 o do Estatuto da Mulher Casada, tal qual foi exposto. $\mathbf{E}$ de se esclarecer que apesar da existência de decisões jurisprudenciais controvertidas, são isoladas as que consideram válido o aval dado pela mulher casada, sem o consentimento do marido, sendo que, ao reverso, são numerosas as que dão pela nulidade do mesmo, a exemplo do Recurso Extraordinário n \% 81.688 - em 21-10-1976, que teve como relator o Ministro Moreira Alves - Jurisprudência Brasileira, vol. 46/47, bem como decisão do Tribunal de Alçada Cível do Estado do Paraná, que, no acórdão sob no 21.617, de 04 de junho de 1985, que teve como Relator o Juiz Francisco Muniz, confirmou por unanimidade sentença de primeiro grau com a seguinte Ementa: "Mulher Casada - Aval - Autorização Marital - Art. 242, IV - Lei no 4.121/62 - art. 39 A muIher casada, não comerciante, para se obrigar cambiariamente, Ther casada, não comerciante, para se obrigar cambiariamente, necessita de outorga marital". 